\title{
Venereology in the British Army in Singapore in 1970
}

\author{
R. N. T. THIN* \\ Venereology Department, British Military Hospital, Singapore
}

As many venereologists once practised in the Armed Forces they may be interested to compare the work of the Venereology Department at the British Military Hospital (B.M.H.) in Singapore during 1970 with their own experience. 1970 was the last full calendar year B.M.H. Singapore was in operation and it had the biggest venereology department in the Army. Singapore Island lies at the southern tip of the Malayan Peninsula and closely resembles the Isle of Wight in size and shape. The city of Singapore is a busy, expanding modern community and has the fourth largest seaport in the world. It is also on the main air route to Australia and New Zealand and is an important communication centre for Asia.

B.M.H. Singapore had all the usual departments found in a general hospital and the laboratory provided satisfactory routine services. For instance, the Venereal Diseases Research Laboratory test and Reiter protein complement-fixation test were done on all sera. Specimens for culture for gonococci were collected in Stuart's transport medium and within a few hours were plated on to chocolate agar without antibiotic supplements. Results appeared to be satisfactory. For example, there was 95 per cent. agreement between Gram-stained smears and cultures in a series of 184 men with urethritis (Thin, Green, and Nicol, 1973). Trichomonal cultures were unsatisfactory; commercial media appeared to deteriorate rapidly and the laboratory's own preparation of Feinberg-Whittington medium also gave poor results. Specimens for the fluorescent treponemal antibody (absorbed) (FTA-ABS) test were sent to London or to the local civilian laboratory. Cervical Papanicolaou smears were sent to London and in an urgent case a report could be obtained within a week.

The garrison consisted of British, Australian, New Zealand, and Gurkha servicemen. There were also Malays and Singaporeans who were members of the British Army. Some of the men were married and the Army was responsible for the medical care of their

Received for publication September 11, 1972

^Present address: Ward 45, Royal Infirmary, Edinburgh

Paper presented at the Jubilee Meeting of the M.S.S.V.D. held in Glasgow, June 8-11, 1972 dependents in Singapore. Normally, an infected soldier first reported to his own doctor who referred him to the department, but some men came directly to the clinic. New cases were seen at any time but subsequent visits were usually by appointment. A number of Royal Navy personnel were also referred for opinion. Women and children were seen by prior arrangement in a room situated in the main outpatient department which was in a separate block from the Venereology Department.

Most of the male patients were single men and usually the primary contact was a local prostitute. Contact tracers attended the department every morning and interviewed all male patients with fresh gonorrhoea or syphilis. In a routine case, in which the contact was a local girl, she was traced the same evening and advised to attend a civilian clinic or her own doctor. When the diagnosis was infectious syphilis the patient often accompanied the contact tracer to assist in correct identification. In this way 90 to 95 per cent. of local contacts were traced.

Wives with social problems were referred to the Soldiers, Sailors, and Air Force Association (SSAFA) sisters, who combine the role of district nurse and health visitor among service communities overseas. They were attached to every general practice serving wives and children and they sometimes helped to trace contacts among families. Impersonal contact slips were not used but occasionally personal letters were sent to contacts among servicemen's families.

\section{Incidence and diagnosis}

In 1970, 1,584 fresh cases were seen; 1,426 in men and 158 in women. The Table (opposite) shows some of the conditions diagnosed.

Among men there were nineteen cases of primary syphilis and nine of secondary syphilis.

The incidence of primary and secondary syphilis among British soldiers in Singapore in 1970 was 2 per 1,000. It was higher among Gurkha soldiers at 8 per 1,000. For comparison, among men in England in 1970, the incidence of primary and secondary 
TABLE Details of cases, by sex and diagnosis

\begin{tabular}{|c|c|c|}
\hline \multirow[b]{2}{*}{ Diagnosis } & \multicolumn{2}{|l|}{ Sex } \\
\hline & Male & Female \\
\hline Syphilis & 56 & 14 \\
\hline Gonorrhoea & 416 & 21 \\
\hline Non-specific genital infection & 357 & 7 \\
\hline Genital warts & 94 & 6 \\
\hline Balanitis & 51 & \\
\hline Vaginal candidosis & & 48 \\
\hline Trichomoniasis & 1 & 18 \\
\hline Pediculosis & 29 & 0 \\
\hline Scabies & 16 & 1 \\
\hline Yaws & 2 & 16 \\
\hline Genital ulceration & 131 & 2 \\
\hline Miscellaneous & 273 & 25 \\
\hline Total & 1,426 & 158 \\
\hline
\end{tabular}

syphilis was 0.04 per 1,000 (Department of Health and Social Security, 1971).

All the cases of syphilis diagnosed in women were in the latent stage. The large proportion of cases of syphilis and yaws found among women was partly due to vigorous contact tracing started early in 1970, and almost all these cases occurred in Gurkha, Malay, and Singaporean women.

There was a relatively higher incidence of syphilis and gonorrhoea than is seen in Great Britain; these two diseases formed 32 per cent. of the total compared with 25 per cent. in British clinics. This higher incidence reflects the prevalence of these conditions in the section of the population of S.E. Asia where most of the men found their sexual partners.

Many of the cases of genital ulceration were probably traumatic in origin and some had the clinical appearance of genital herpes simplex, but virological studies were not carried out. A few looked like chancroid but microbiological confirmation was not obtained. There were a number of cases in which the clinical diagnosis of lymphogranuloma venereum (LGV) was supported by the results of the LGV complement-fixation test in acute and convalescent sera. There were, in addition, cases in which the clinical diagnosis was LGV but the LGV complement fixation test was negative.

There were more cases of genital warts and penile ulceration than are seen in army clinics in Britain. On the other hand there were fewer cases of scabies and pediculosis. Compared with some civilian clinics there were few requests for examination from asymptomatic persons.

Interesting cases included annular, corymbose, and pustular eruptions of secondary syphilis. There were two patients with balanitis xerotica obliterans, one of whom could hardly micturate through a tiny meatus, though he was a very active infantry soldier. There was one case of acute gonococcal tysonitis without urethritis, and one man had benign papillary cystadenomas of both epididymes. One case of infectious syphilis with a Herxheimer reaction following the first and second daily injections of penicillin has already been reported (Thin, 1971), and a second similar case was also seen. Special studies included: further assessment of immunofluorescence in the diagnosis of gonorrhoea (Thin and others, 1973), a clinical study of syphilis among Gurkhas (Thin, 1972), and the treatment of gonorrhoea (Thin, 1973). Of 400 cases of gonorrhoea treated with 1g. probenecid by mouth followed after 30 minutes by an injection of 5 m.u. benzyl penicillin, 378 were followed and five relapsed ( 1.3 per cent.) (Thin, 1973).

On the whole the organization for dealing with sexually transmitted disease worked well, with one exception. This was the referral of wives with social problems to SSAFA sisters. Previous experience with medico-social workers based in hospital had been very satisfactory, and it had been hoped that a similar liaison could be developed with communitybased workers, who might learn more about the patients. However, none of the patients knew their particular sister before coming to see me, and few were willing to be referred. When a sister did contact a wife it was often a great help. After a time it was decided to obtain the services of a sister once a week at the female clinic, but the run-down of the garrison prevented this. It is concluded that a medico-social worker should be an integral member of the staff of every venereology department, including departments in the Armed Forces.

Another aspect of the work at Singapore deserves to be mentioned. Close liaison was established with the urological surgeon. A combined clinic was held once a month where cases of mutual interest, such as prostatitis, were reviewed, and this experience proved very valuable. At first the clinic was held in the surgical outpatient department but latterly it was held in the venereology department where the facilities were considered to be better. This proved acceptable to patients, doctors, and staff and, it is believed, provides a useful pattern for other clinics.

\section{Summary}

The facilities and work of the Venereology Department at the British Military Hospital in Singapore during 1970 are outlined. 1,426 fresh male cases and 158 fresh female cases were seen. There were relatively more cases of gonorrhoea and syphilis than are seen in Great Britain, and 90 to 95 per cent. of 
local contacts of these cases were traced. Routine laboratory services were satisfactory, apart from culture for trichomonads. Difficulties were encountered referring patients to community based social workers, but otherwise the normal working of the department was satisfactory.

Among the rarer cases seen were late cutaneous manifestations of secondary syphilis and a patient with benign papillary cystadenomas of both epididymes.

\section{References}

Department of Health and Social Security (1971)

'On the state of the Public Health. Report of the Chief Medical Officer for 1970', p.61. H.M.S.O., London

ThIN, R. N. T. (1971) Brit. F. vener. Dis., 47, 293 (1972) Ibid., 48, 189

(1973) Ibid., 49, in press

-, GREEN, F., and NICOL, C. S. (1973) In preparation

\section{La vénéréologie dans l’armée britannique à Singapour en 1970}

SOMMAIRE

On met en évidence l'équipement et le travail du Département de Vénéréologie à l'Hôpital britannique militaire de Singapour en 1970. Il a été vu 1.426 cas nouveaux chez les hommes et 158 cas nouveaux chez les femmes. Relativement, il y eut plus de cas de gonococcie et de syphilis que ce que l'on voit en Grande-Bretagne et 90-95 pour cent des contacts locaux purent être identifiés. Les services de routine du laboratoire furent satisfaisants, sauf pour la culture du Trichomonas. On rencontra des difficultés pour que les malades s'adressent aux travailleurs sociaux locaux de la communauté mais, ceci à part, le travail normal du département fut satisvaisant.

Parmi les cas rares qui furent vus, se trouvent une syphilis secondaire à manifestations cutanées tardives et un malade avec un cystadénome papillaire des deux épididymes. 